\title{
A hybrid optimization model of biomass trigeneration system combined with pit thermal energy storage
}

\author{
D.F. Dominkovića ${ }^{a}$, B. Ćosić ${ }^{\mathrm{a}, *}$, Z. Bačelić Medić ${ }^{\mathrm{b}}$, N. Duić ${ }^{\mathrm{a}}$ \\ ${ }^{a}$ Faculty of Mechanical Engineering and Naval Architecture, University of Zagreb, Zagreb, Croatia \\ ${ }^{\mathrm{b}}$ iC artprojekt ltd, Varaždin, Croatia
}

\section{A R T I C L E I N F O}

\section{Article history:}

Available online 2 April 2015

\section{Keywords:}

Trigeneration

Seasonal storage

Optimization

Biomass

Feed-in tariff

Feed-in premium

\begin{abstract}
A B S T R A C T
This paper provides a solution for managing excess heat production in trigeneration and thus, increases the power plant yearly efficiency. An optimization model for combining biomass trigeneration energy system and pit thermal energy storage has been developed. Furthermore, double piping district heating and cooling network in the residential area without industry consumers was assumed, thus allowing simultaneous flow of the heating and cooling energy. As a consequence, the model is easy to adopt in different regions. Degree-hour method was used for calculation of hourly heating and cooling energy demand. The system covers all the yearly heating and cooling energy needs, while it is assumed that all the electricity can be transferred to the grid due to its renewable origin. The system was modeled in Matlab $\odot$ on hourly basis and hybrid optimization model was used to maximize the net present value (NPV), which was the objective function of the optimization. Economic figures become favorable if the economy-of-scale of both power plant and pit thermal energy storage can be utilized. The results show that the pit thermal energy storage was an excellent option for storing energy and shaving peaks in energy demand. Finally, possible switch from feed-in tariffs to feed-in premiums was assessed and possible subsidy savings have been calculated. The savings are potentially large and can be used for supporting other renewable energy projects.
\end{abstract}

(c) 2015 Elsevier Ltd. All rights reserved.

\section{Introduction}

Worldwide demand for energy is increasing; as a consequence fossil fuel resources are becoming more and more expensive, in the same time making renewable energy resources more competitive. The European Union has adopted 20-20-20 targets until 2020 , which means increased energy efficiency by $20 \%$, reduced greenhouse gas emissions by $20 \%$ and reaching a $20 \%$ share of renewable in total energy generation [1]. In the EU's 2030 framework for climate and energy policies presented in January 2014, continuing progress toward a low-carbon economy is expected [2]. The most important objective by 2030 is to reduce the greenhouse gas emissions by $40 \%$ below the 1990 level, while increasing the renewable energy share to at least $27 \%$. In order to achieve this target, improvements in the energy efficiency are needed.

One good example in improving energy efficiency throughout the year is combined production of electricity, heating and cooling energy in trigeneration [3]. At the same time, using biomass as a

* Corresponding author at: I. Lučića 5, 10000 Zagreb, Croatia. Tel.: +38598168 8149 .

E-mail addresses: dominik6@gmail.com (D.F. Dominković), boris.cosic@fsb.hr (B. Ćosić), z.bacelic@ic-group.org (Z. Bačelić Medić),neven.duic@fsb.hr (N. Duić). fuel for the trigeneration power plant increases the renewable energy share in the overall production mix. Rentizelas et al. [4] provide an optimization model for energy supply based on multibiomass trigeneration, covering peak demand with a biomass boiler. Puig-Arnavat et al. [5] assessed different trigeneration configurations based on biomass gasification. Borsukiewicz-Godzur et al. [6] calculated results for three variants of combined heat and power (CHP) biomass plants. A techno-economic assessment of biomass fuelled trigeneration system was made by Huang et al. [7]. Recently, Wang et al. [8] published a paper dealing with multi-objective optimization of a combined cooling, heating and power system driven by solar energy. Zhao et al. [9] analyzed the energy efficiency level for a station in China, which uses a trigeneration system. Although this is still a small-scale trigeneration system, used for a single building, interesting economic figures have been achieved, i.e. simple pay-back time of the additional investment was 5.47 years. There are also papers dealing with micro-trigeneration system such as Angrisani et al. [10], where a trigeneration system on a small-scale is assessed. Nevertheless, Kilkiş [11] developed a model for the net-zero exergy district development for a city in Sweden, which among other units includes a CHP plant with district heating and cooling system. 
In the simultaneous generation of electricity, heating and cooling energy, the system should be optimized to follow heating energy demand in order to achieve maximum efficiency of the useful energy being utilized. Please note here that due to the renewable nature of the biomass being considered, electricity generated has preference when supplying to the grid and thus, it is considered that all the electricity can be transferred to the grid at anytime. On the other hand, the feed-in tariff for electricity is the most important income for investors in trigeneration power plant. In order to be eligible to receive feed-in tariff, minimum overall yearly power plant efficiency has to be reached. One way of achieving high, relatively constant heat demand is to use dryers for reducing the moisture content in biomass. Currently, legislation in Croatia allows this, but it is questionable if it will be allowed in the future as it is not the most efficient way of using the heat energy. According to Härkönen [12], after reaching the equilibrium moisture, which will happen naturally, after a required period of time when exposed to the outside air, heat of desorption increases linearly as the moisture content is getting lower. The biomass in Croatia is delivered to the power plant with up to $30 \%$ of moisture, after which the heat needed for drying biomass increases significantly by reducing the moisture content in biomass. Moreover, the increased size of wood significantly increases energy consumption in dryers and drying can become unprofitable as shown by Gebreegziabher et al. [13]. Thus, the drying will not be considered as an option to utilize heat in this paper. As a consequence of not having a constant heat consumer, seasonal thermal energy storage will be incorporated in the optimization model in order to deal with the peak demand, as well as with large differences in heating and cooling energy demand throughout the seasons.

Currently in Croatia, for the system being assessed, only feed-in tariffs for cogeneration power plants or biomass electric power plants would be applicable, while the feed-in tariffs for trigeneration systems do not exist. Both options are at the same level for the capacities being considered in this paper. However, feed-in tariff for the pit thermal energy storage (PTES) would be of great significance for the economic feasibility of investment. Krajačić et al. [14] provided an overview of potential feed-in tariffs for different energy storage technologies. For the system being assessed, the triple tariff, as discussed in Lund and Andersen [15], would be significantly supportive toward the economic viability of the chosen system. Furthermore, neither a feed-in tariff for district heating and cooling network is available in Croatia. As shown in Rezaie and Rosen [16], district heating in densely populated regions would be a favorable investment compared to low-density residential areas. However, in this case study, a neighborhood consisting of family houses was considered.

Nevertheless, the importance of seasonal heat storage in a future sustainable energy system in Croatia was assessed by Krajačić et al. [17]. Without seasonal heat storage, critical excess in electricity production, as well as intermittency of wind power plants production, will be difficult to deal with.

Up to now, most papers have dealt with the solar thermal energy coupled with the seasonal energy storage [18-22]. Raine et al. [23] optimized combined heat and power production for buildings using a heat storage. However, storage volumes in two different scenarios had volumes of only $600 \mathrm{~m}^{3}$ and $350 \mathrm{~m}^{3}$. Thus, these were not large-scale seasonal storages. Rezaie et al. [24] assessed exergy and energy efficiencies of a seasonal hot water storage combined with solar collectors and boilers. When there is no instant need for heating energy, it can be stored in the large-scale pit thermal energy storage and used later when there will be need for the heating energy. In Mangold [25], it is shown that the economy-of-scale is significant till water storage volumes of $50,000 \mathrm{~m}^{3}$. Moreover, according to Energo Styrelsen's publication [26], the economy-of-scale for the low capacity range is quite considerable.

The novel approach in this paper is a combination of large scale seasonal pit thermal energy storage and biomass trigeneration power plant. The model will be developed in order to make the most of economy-of-scale. Moreover, in order to develop the model which can be easily replicated, only residential buildings will be considered as heat consumers. From the demand side point of view this is the worst case for covering the heating and cooling load throughout the year as there is no constant need for heating or cooling energy.

Furthermore, the guidance for the design of renewables' support schemes [27] has been issued by the European Commission. Feed-in premiums, variable or fixed, were given preference over feed-in tariffs. Under the feed-in tariff, power plants do not trade any electricity on the market; they rather receive a fixed amount of subsidy per energy unit of generated electricity. On the other hand, under both variable and fixed feed-in premiums, power plant trades the electricity generated on the market, on top of which it receives a premium, which should fairly compensate the costs of generating the energy from the renewable energy sources. In the case of fixed feed-in premium, there is a larger risk placed on an investor, as the amount of subsidy on top of the market price is fixed. In the case of variable feed-in premium, a lower risk is imposed on the investor as the total amount of income per unit of energy generated is guaranteed to the investor and known in advance. Variable premium changes as the price on the market changes, keeping the total income per unit of energy generated constant. In both variable and fixed premiums, one part of the income for the investor is received from the market, reducing the total subsidy needed to be paid off by the governmental body or agency.

As Croatia has implemented feed-in tariffs as a renewables' support scheme, this paper will also estimate levels at which feed-in premiums, both variable and fixed, should be set to in order to replace the current mechanism. At the end of 2013, seven countries in the EU28 were using feed-in premiums or combination of feedin premiums and other supporting schemes [28]. Other common supporting schemes are green certificates and tenders. So far, feed-in systems proved to be more efficient than the green certificates [29]. Potential savings in expenditure on subsidies by the government, by adopting feed-in premiums, were assessed, too.

\section{Methodology}

\subsection{Problem definition}

An investor who decides to invest funds wants to maximize profit. In a trigeneration power plant the crucial role for maximizing income is the generated electricity sold at a price set by a feedin tariff. Consequently, the best way to maximize profit would be to produce as much electricity as possible. On the other hand, technically, the system is driven by heat demand in order to maximize efficiency. In order to satisfy both economic and technical targets, the feed-in tariff eligibility is usually constrained by a minimum overall efficiency of the power plant. In Croatia, the minimum average yearly efficiency needs to be above $50 \%$ [30] in order to receive the maximum feed in tariff, while some other examples include Austria (60\%), Greece (65\%) and Ireland (70\%) [31]. Taking this into account, the model is possible to be adopted and used in many European countries. In order to have a constant electricity production, while still having an overall efficiency above the minimum allowed level, a relatively constant heat demand is needed. However, as it is shown that the heat demand has a strong 
seasonal pattern, especially in housing dwellings [32,33], there is a need to develop a model which will offset high seasonality. Thus, the scope of this paper is to answer the research question: "How should a district heating and cooling (DHC) system, including a biomass fired CHP plant, absorption chillers and a PTES, be dimensioned in order to maximize the NPV depending on system efficiency requirements for feed-in tariff eligibility?".

The system efficiency is defined by the ratio of usefully delivered energy and the total fuel consumption (in this case biomass). Term usefully delivered energy covers all the electricity delivered to the electrical grid, no matter what the demand for the electricity in the specific area is, and heating and cooling energy consumed by the end-consumers (households). Consequently, heat stored in the thermal energy storage and later used by the consumers is considered as a usefully delivered energy.

\subsection{Model description}

The model optimizes the sizes of the seasonal thermal storage, the biomass power plant and the absorption units which are subject to different constraints. The decision maker can set the targeted overall efficiency of the power plant. The first target of the system is to fully cover the heating and cooling energy demand. As a consequence, seasonal energy storage, besides storing energy in periods with lower demand, shaves peaks in heating energy demand for periods with higher demand, which usually occur during the winter season. This means that a peak boiler is not necessary in the system. It is assumed that all the electricity produced in the power plant can be sold to the network for the price specified by the feed-in tariff. The produced heat can be used for district heating, district cooling by using absorbers, or stored in the energy storage. The three main system components are the biomass power plant, absorbers and the seasonal pit thermal energy storage (PTES) (Fig. 1).

The interactions within the systems can be easily understood by studying logic tree shown in Fig. 2.

To sum up, the system presented will cover all the heating and cooling energy demand by the consumers in the considered area, as well as produce a significant amount of electricity, which will be transferred to the electrical grid, no matter what the generation amount equals to.

\subsection{Biomass power plant}

The biomass power plant size is calculated, taking into account the heating and cooling demand. As the model is heat driven, the electricity generating capacity follows the heat consumption throughout the year. As an average biomass power plant has the availability of approximately 90\%, the model calculates the part of the year with the lowest energy demand where the biomass power plant is shut down for maintenance. During this period the heating/cooling demand is completely covered by the seasonal energy storage.

\subsection{Heating and cooling demand}

Heating and cooling demand are calculated by using degree hours, based on hourly temperatures valid for the considered location. Yearly heating and cooling energy consumption per $\mathrm{m}^{2}$ has to be assumed by the decision maker for the specific location. The district heating and cooling network consist of double piping each, thus, allowing simultaneous cooling and heating energy flow. This is of great importance during the summer, when the demand for cooling energy exists due to high temperatures, as well as for the heating energy for the domestic hot water (DHW) preparation. Moreover, this also allows the model to be adopted by industrial consumers, as it is possible to provide both heating and cooling energy simultaneously (see Figs. 1 and 2).

Calculated total heating energy for space heating, DHW preparation, as well as the cooling energy demand is shown in Fig. 3. The DHW distribution has been adopted from the ASHRAE standard [34].

\subsection{Absorbers}

Absorbers in the system are driven by the heat generated from the biomass power plant. They can be driven directly by the produced heat in power plant or by the heat stored in the seasonal energy storage. Absorbers were preferred, compared to adsorbers, because they have a lower investment cost. As it is predicted that the water in the seasonal storage will be stored with temperatures between $85^{\circ} \mathrm{C}$ and $90^{\circ} \mathrm{C}$, the predicted $\mathrm{LiBr}-\mathrm{H}_{2} \mathrm{O}$ single effect absorbers are able to work properly [35,36].

\subsection{Seasonal energy storage}

Pit thermal energy storage (PTES) was chosen for the seasonal heat energy storage mostly due to low investment cost. Water as a storage media is a well-developed solution and so far, the only mature technology for large volume storages. According to [37], PTES are the largest thermal energy storages being built. Typical efficiency of such storage is between $80 \%$ and $95 \%$, depending on the temperature level in the storage [26]. As economy-of-scale after volume of $50,000 \mathrm{~m}^{3}$ does not apply, it is possible to build a few PTES instead of one if the storage volume in the model becomes very large.

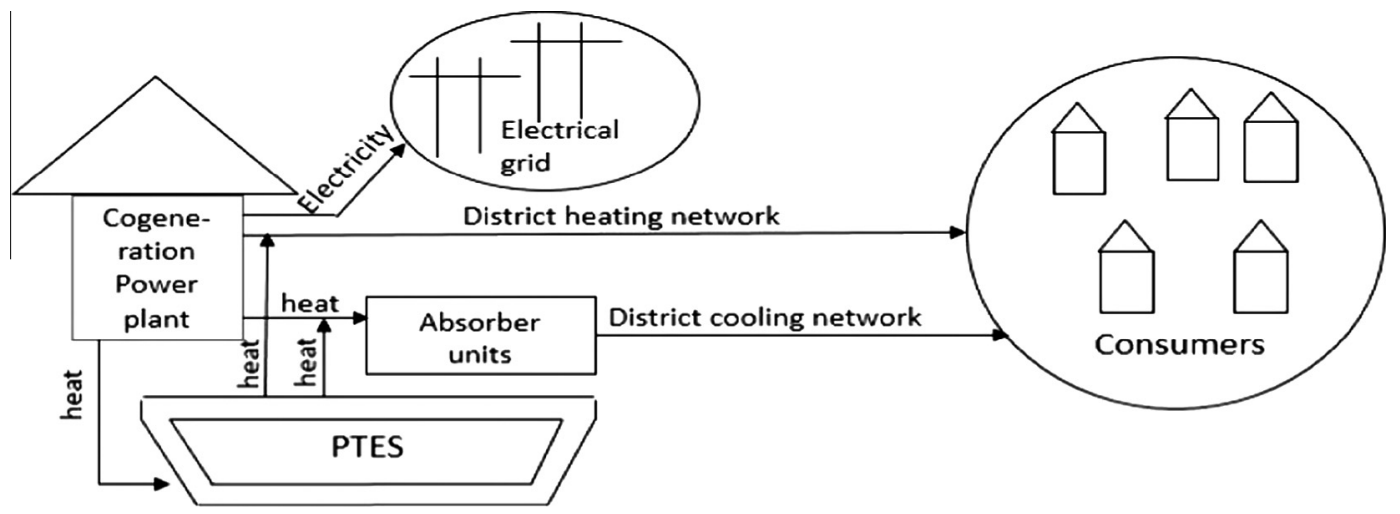

Fig. 1. The scheme of the modeled system. 


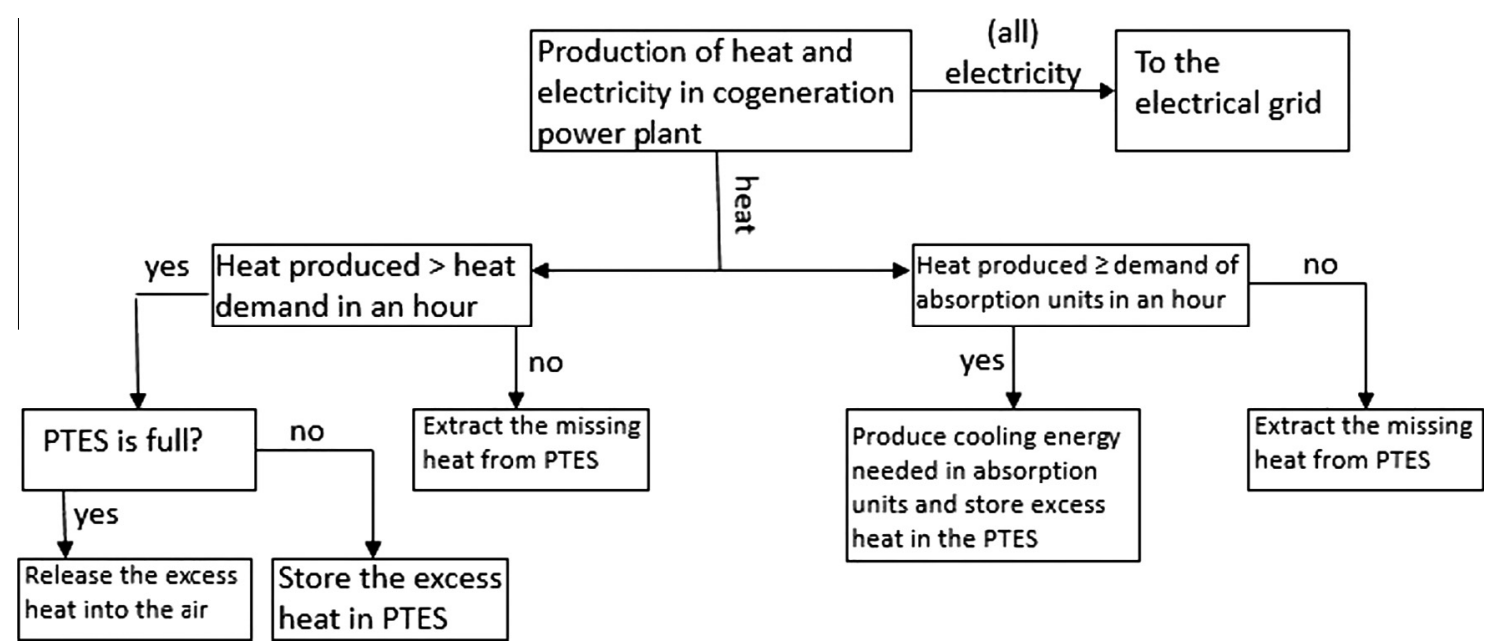

Fig. 2. A logic tree representation of the decisions made by the technological system.

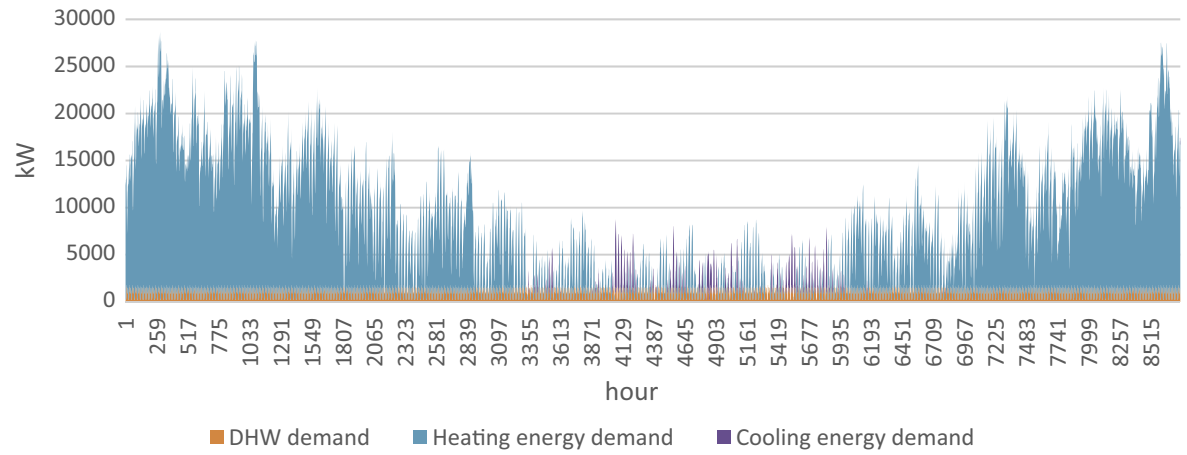

Fig. 3. Heating and cooling energy demand for the city of Osijek.

The average yearly efficiency of the seasonal thermal energy storage in this model is set to $80 \%$ and is independent of the time that the heat is stored. This simplification is valid as the seasonal storage is mostly used for the storage of the heat during the longer period of time, which can be used as a reference for calculating the average efficiency of the storage. Moreover, for such large capacities, as it is the case with this model, the surface-to-volume ratio declines rapidly, which significantly reduces a heat exchange surface on the walls of the storage. Thus, picking a lower average efficiency from the efficiency span reported in the literature [26] is a valid assumption.

\section{Clean Energy and Sustainability}

\subsection{Optimization variables}

Three independent variables determined by the optimization model are:

$P_{e l}$ - electricity generating capacity of the biomass trigeneration power plant in $\mathrm{kW}_{\mathrm{e}}$. The heat capacity $\left(P_{e l}\right)$ is proportional to the electricity generating capacity, following assumed fixed heat-to-power ratio.

$S_{V}$ - volume of the storage in $\mathrm{m}^{3}$.

$P_{A}$ - capacity of the absorber unit(s) in kW.

\subsection{Objective function}

Maximizing net present value for the project lifetime, during which feed-in tariff is assumed as guaranteed, was the objective in the optimization model. Although a biomass power plant has a much longer lifetime, this assumption was introduced in order to reduce vagueness about the future electricity price predictions. The optimization model also calculates the internal rate of return (IRR) and the simple pay-back period in order to provide enough inputs for the decision making process. The NPV function is:

$$
\begin{aligned}
N P V= & \left(I_{h}+I_{c}+I_{e l}-E_{O M, B f}-E_{O M, B v}-E_{O M, D H C n}-E_{O M, S}-E_{f B}\right) \\
& \cdot D-I n v_{B}-\operatorname{In} v_{A}-\operatorname{In} v_{D H C N}-\operatorname{In} v_{S}
\end{aligned}
$$

where all the future annual income and expenditure values are multiplied by a discount coefficient $D$ :

$D=\frac{1}{(1+i)^{t}}$

where $i$ is the discount rate and $t$ is the project lifetime.

\subsubsection{Income}

There are three income items in the model; revenues from electricity, heating and cooling energy sales. As the power plant needs to satisfy all the need for heating and cooling energy, it can be assumed that all the heating and cooling energy need for the district considered is sold from this power plant. Income from the heat sales during the one year $I_{h}$ equals:

$I_{h}=h_{P} \sum_{j=1}^{8760} h_{j}$

where $h_{P}$ is the price of $\mathrm{kWh}$ of heat, $h_{j}$ is the hourly value of heat demand $(\mathrm{kWh})$ throughout the year. $I_{c}$ is the income from the sales of cooling energy: 
$I_{c}=C_{P} \sum_{j=1}^{8760} c_{j}$

where $C_{P}$ is the price of $\mathrm{kWh}$ of the cooling energy and $c_{j}$ is the hourly value of the cooling demand $(\mathrm{kWh})$ throughout the year. $I_{e l}$ is the income from the sales of electricity:

$I_{e l}=E_{P} \sum_{j=1}^{8760} e_{j}-e_{p p}$

where $E_{P}$ is the price of kWh of electricity, $e_{j}$ is the hourly value of electricity production $(\mathrm{kWh})$ and $e_{p p}$ is the power plant's own electricity consumption throughout the year.

\subsubsection{Expenditure}

There are five expenditure items; fixed and variable operating and maintenance cost of the biomass power plant, operating costs of district heating and cooling network and thermal energy storage and cost of fuel, which is biomass in this case.

$E_{O M, B v}$ is the expenditure on variable O\&M:

$E_{O M, B v}=V \sum_{j=1}^{8760} e_{j}$

where $V$ is the variable cost of $O \& M\left(€ / \mathrm{kWh}_{\mathrm{e}}\right)$.

$E_{O M, B f}$ is the expenditure following fixed O\&M cost:

$E_{O M, B f}=F \cdot P_{e l}$

where $F$ is the fixed yearly $0 \& M$ cost $\left(€ / \mathrm{kW}_{\mathrm{e}}\right)$.

$E_{O M, D H C n}$ is the O\&M cost of district heating and cooling network:

$E_{\mathrm{OM}, \mathrm{DHCn}}=Z \cdot N$

where $Z$ is the number of dwellings in a district considered and $N$ is the cost of yearly network maintenance ( $€$ /dwelling).

$E_{O M, S}$ is the O\&M cost of storage:

$E_{O M, S}=U \cdot S_{V}$

where $U$ is the $0 \& M$ price of the yearly storage maintenance $\left(€ / \mathrm{m}^{3}\right)$.

$E_{f B}$ is the expenditure on fuel (biomass):

$E_{f B}=B \cdot \frac{1}{h_{d}} \cdot \frac{1}{\eta_{e l}} \cdot \sum_{j=1}^{8760} e_{j}$

where $B$ is the price of biomass ( $€ /$ ton), $h_{d}$ is the lower calorific value of biomass (kWh/ton) and $\eta_{e l}$ is the electrical efficiency of the power plant.

\subsubsection{Investment}

The overall investment consists of four parts; investment in the biomass power plant, in absorption chillers, in district heating and cooling networks and in the pit thermal energy storage. Investment in the biomass power plant $\operatorname{In} v_{B}$ is calculated as follows:

$\operatorname{In} v_{B}=B_{i n v} \cdot P_{e l}$

where $B_{i n v}$ is the price of investment per power plant capacity ( $€$ / $\mathrm{kW} \mathrm{el}) \cdot \operatorname{In} v_{A}$ is the price of investment in absorption chillers:

$\operatorname{Inv} v_{A}=A_{\text {inv }} \cdot C_{\text {peak }} \cdot \frac{1}{\mathrm{COP}}$

where $A_{i n v}$ is the price of investment per absorption capacity $(€ /$ $\mathrm{kW}), C_{\text {peak }}$ is the peak demand for cooling energy (kW) and COP is the coefficient of performance of the absorption units. As mentioned before, the model predicted that all the cooling energy needs to be satisfied from this power plant, thus the needed capacity of absorption units is equal to peak cooling demand divided by the coefficient of performance, which was set in this model to 0.7.

Investment in the district heating and cooling network In $v_{\mathrm{DHCN}}$ is calculated as follows:

$\operatorname{In} v_{D H C N}=N_{\text {inv }} \cdot Z$

where $N_{i n v}$ is the investment per dwelling ( $€ /$ dwelling). In this model $N_{i n v}$ was used from Ref. [38].

Investment in the pit thermal energy storage $\operatorname{In} v_{S}$ :

$\operatorname{In} v_{S}=S_{i n v} \cdot S_{V}$

where $S_{i n v}$ is the price of storage investment $\left(€ / \mathrm{m}^{3}\right)$, which was implemented in this model from Ref. [26].

\subsection{Constraints}

The heat demand in every hour $j$ throughout the year needs to be covered, either by biomass power plant production, by heat stored in PTES, or by both sources of heat:

$h_{B, j}+h_{S_{V} j} \geqslant h_{j}$

where $h_{B, j}$ is the hourly heat production in the biomass power plant and $h_{S_{V} j}$ is the heat taken from PTES on an hourly basis.

Heat used in the absorption units needs to cover the cooling demand in every hour $j$ throughout the year:

$\left(h_{B, j}+h_{S_{V}, j}\right) \cdot \frac{1}{C O P} \geqslant c_{j}$

The sum of the heat production capacity of the biomass power plant and the heat from the storage that can be taken has to be larger or equal to peak heat demand:

$P_{e l} \cdot H T P+S_{V} \cdot \rho_{w} \cdot c_{p} \cdot \Delta T \cdot \frac{1}{3600} \cdot \eta_{S} \geqslant h_{\text {peak }}$

where HTP is the heat-to-power ratio, $\rho_{w}$ is the density of water $\left(\mathrm{kg} / \mathrm{m}^{3}\right), c_{p}$ is the specific heat capacity of water $(\mathrm{kJ} /(\mathrm{kgK})), \Delta T$ is the difference in temperature of stored water and the design temperature of the dwellings' heating systems $(\mathrm{K}), \eta_{S}$ is the efficiency of the PTES and $h_{\text {peak }}$ is the peak heat demand $(\mathrm{kW})$.

The cooling energy peak demand needs to be covered in the same manner as the heating energy peak demand:

$P_{e l} \cdot H T P \cdot C O P+S_{V} \cdot \rho_{w} \cdot c_{p} \cdot \Delta T \cdot \frac{1}{3600} \cdot \eta_{S} \cdot C O P \geqslant c_{p e a k}$

Storage volume size has to be able to store all the heating energy which needs to be taken at certain time from the PTES:

$h_{S_{V}, \text { sum }} \cdot 3600 \cdot \frac{1}{c_{p}} \cdot \frac{1}{\Delta T} \cdot \frac{1}{\rho} \cdot \frac{1}{\eta_{S}} \geqslant S_{V}$

where $h_{S_{V} \text { sum }}$ is the sum of heating energy which needs to be taken from the storage in the longest period of time where average biomass heat production rate is lower than heat demand (under the term "heat demand", "cooling energy demand" is also assumed, which is the same in this model except COP coefficient which needs to be taken into account).

$e+h \geqslant P_{e l} \cdot \frac{1}{\eta_{e l}} \cdot B_{a v} \cdot 8760 \cdot \eta_{X}$

where $e$ and $h$ present the produced electricity and heat demand during one year of power plant operation, $\eta_{e l}$ is the electrical efficiency of the power plant, $B_{a v}$ is the availability of the biomass power plant and $\eta_{X}$ is the minimum overall efficiency power plant needs to have to be eligible to receive subsidy. 


\subsection{Optimization method}

A hybrid optimization method was used to optimize this problem. As this is a non-linear problem, a Genetic Algorithm and fmincon were used in Matlab@. The Genetic Algorithm has been recently applied in several papers for the optimization of the energy systems, such as in optimization of low-temperature district heating network [39]. It is a useful optimization method, which approaches to a global optimum very fast because it generates a population of points at each iteration, instead of a single point at each iteration in a classical algorithm [40]. However, it converges relatively slowly when it reaches a solution close to the global optimum. Thus, after Genetic Algorithm, fmincon starts and finds a minimum of the constrained nonlinear multivariable function [40]. However, fmincon needs to have a good initial point in order to end up in the global optimum instead of a local optimum. Thus, hybrid programming optimization method has proven to be very effective for this type of problem.

\section{Case study: the city of Osijek}

The model was applied to a district in the city of Osijek. Osijek is one of the four largest cities in Croatia. 2000 dwellings with $200 \mathrm{~m}^{2}$, with an average spacing of $10 \mathrm{~m}$ between each of them were assumed. In Croatia, the yearly average heating energy consumption is rather high and $160 \mathrm{kWh} / \mathrm{m}^{2}$ of heating energy per annum was assumed. In order to be eligible for the feed-in support, in Croatia, overall yearly efficiency of the power plant has to be above $50 \%$ [30]. Biomass moisture is considered to be relatively constant at $30 \%$ as this is the usual case in Croatia. Input data for the case study are presented in Table 1.

Three case studies were conducted, with minimum yearly average power plant efficiencies of 50\%, 65\% and 75\%, respectively. The first number was chosen in order to represent a current situation in Croatia, where the minimum yearly efficiency needed, in order to be eligible for the maximum feed-in tariff is more than $50 \%$. The $65 \%$ efficiency was chosen in order to represent the situation where the efficiency level currently used in Greece would be

Table 1

List of data used in case study.

\begin{tabular}{llll}
\hline & Amount & Unit & Ref. \\
\hline Power plant availability & 0.9 & & {$[26]$} \\
Biomass price & 38.5 & $€ /$ ton & {$[41]$} \\
$\begin{array}{l}\text { Lower calorific value }(30 \% \\
\quad \text { moisture })\end{array}$ & 3500 & $\mathrm{kWh} /$ ton & {$[42]$} \\
$\eta$ power plant total & & & \\
$\eta_{\text {el }}$ & 0.89 & & {$[26]$} \\
HTP ratio & 0.3 & & {$[26]$} \\
$\eta$ storage & 1.97 & & {$[26]$} \\
Storage temperature & 0.8 & & {$[26]$} \\
$B_{\text {inv }}$ & 90 & ${ }^{\circ} \mathrm{C}$ & {$[26]$} \\
$A_{\text {inv }}$ & 3600 & $€ / \mathrm{kW}$ & {$[26]$} \\
$N_{\text {inv }}$ & 400 & $€ / \mathrm{kW}$ & {$[43]$} \\
$S_{\text {inv }}$ & 8150 & $€ / \mathrm{dwelling}$ & {$[38]$} \\
Plant own electricity consumption & $6 \%$ & $€ / \mathrm{m}^{3}$ & {$[44]$} \\
Discount rate & $7 \%$ & & \\
Feed-in tariff & 0.156 & $€ / \mathrm{kWh}$ & \\
COP & 0.7 & & {$[30]$} \\
Design temperature for heating & 21 & ${ }^{\circ} \mathrm{C}$ & {$[43]$} \\
Design temperature for cooling & 26 & ${ }^{\circ} \mathrm{C}$ & \\
$F$ & 29 & $€ / \mathrm{kW}$ per annum & {$[26]$} \\
$V$ & 0.0039 & $€ / \mathrm{kWh}$ & {$[26]$} \\
$N$ & 75 & $€ / \mathrm{dwelling}$ per & {$[38]$} \\
& & annum & \\
$U$ & 0.39 & $€ / \mathrm{m}^{3}$ per annum & {$[26]$} \\
$h_{P}$ & 0.0198 & $€ / \mathrm{kWh}$ & \\
$C_{P}$ & 0.0198 & $€ / \mathrm{kWh}$ & \\
Project lifetime & 14 & years & \\
\hline
\end{tabular}

adapted to the Croatian system. The last efficiency, amounting to $75 \%$, was chosen in order to represent a possible future stringent measures adopted in order to reduce inefficient use of energy even more. A sensitivity analyses were performed and the influence of the biomass price on overall results was investigated. The second parameter that was checked in the sensitivity analyses was the reduced heat and cooling demand due to increased thermal energy savings which resulted after applying a better insulation. Many programs of improving insulation properties are being carried out in Croatia, where the government supports the investment up to $47 \%$ [45]. Thus, in this case a shift from energy class $E$ to energy class $C$ was assumed.

\section{Results and discussion}

\subsection{Case study 1}

In this case study, with the minimum yearly power plant efficiency of 50\%, all economic indicators are good and this investment would be profitable for the investor. The NPV equals to $39,630,000 €$, IRR is $15.0 \%$ and the simple pay-back time is 5.72 years. Optimal capacity of the power plant is $14,675 \mathrm{~kW}_{\mathrm{e}}$. The results would be even better if a higher heat price could be achieved, but it was decided to use the cheaper than best alternative approach in order to be certain that customers would shift to a new heat supply option. The storage size in this case would be $30,350 \mathrm{~m}^{3}$. The heat from the storage in this case is only used during the time when the biomass power plant is not producing heat due to regular yearly maintenance work. In Fig. 4 the use of storage for peak energy demand can be seen.

One could argue here that the PTES is not a necessary component of the system, since it is rarely used. A possible substitute could be a small back-up hot water boiler. However, this is not the case as it can be seen from the calculation in Table 2. It is important to keep in mind that the heating energy stored in the PTES and later used by the consumers is considered as usefully delivered energy by the cogeneration plant system. If the small back-up boiler would be used instead of the seasonal storage, the amount of heat used from PTES now would be released into the air. Thus, the total yearly efficiency, calculated as explained in the Section 2.1, would drop below 50\%. In order to tackle this issue, the cogeneration plant should be resized and lower its capacity in order to stay above the efficiency requirements for the feed-in tariff eligibility.

As it can be seen from the table, although running the biomass boiler instead of PTES, in the case with the minimum yearly efficiency of $50 \%$, is cheaper from the investment point of view, the option with the PTES is a better choice in the system organized in this way, as it enables the larger capacity of the cogeneration power plant to be installed in the first place, which contributes to the better economic indicators in overall. Increasing the minimum yearly efficiency to higher levels, this saving becomes larger and larger.

\subsection{Case study 2}

Although the economic indicators in this case are slightly less favorable from the investor's point of view compared to the case study 1 , it is nevertheless still economically feasible investment. In this case, in which the minimum yearly efficiency is set to $65 \%$, a current efficiency level set by legislation in Greece, the NPV of the project amounts to $15,320,000 €$, IRR is $11.5 \%$ and the simple pay-back time equals 6.78 years. Optimal capacity of the cogeneration plant is $8270 \mathrm{~kW}_{\mathrm{e}}$. 


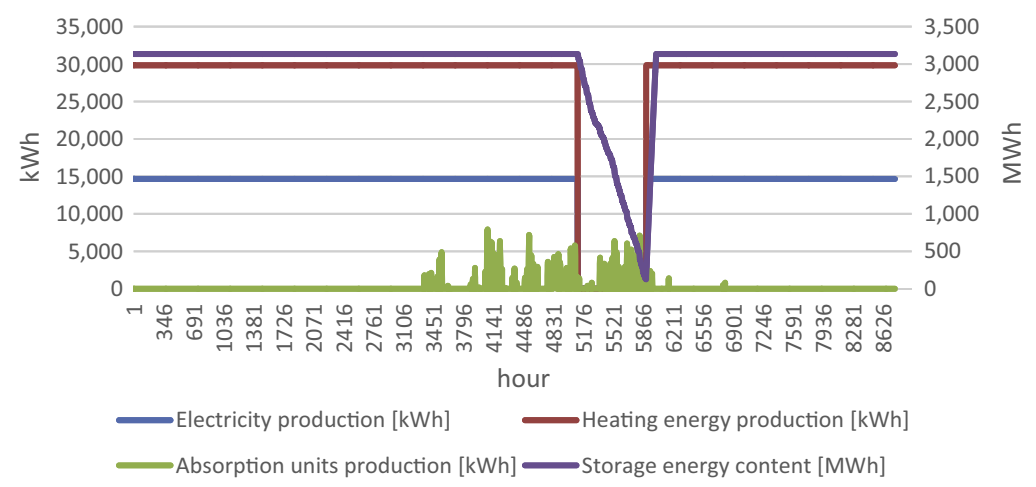

Fig. 4. Operation of the system in the case study 1 .

Table 2

Comparison of the two technologies in the district heating system.

\begin{tabular}{llll} 
& $\begin{array}{l}\text { Peak biomass } \\
\text { boiler }\end{array}$ & PTES & \\
\hline Efficiency & 0.97 & 0.8 & \\
Investment & $100 € / \mathrm{kW}$ & $56 € / \mathrm{m}^{3}$ & $€ / \mathrm{kW}$ \\
Maximum load & 7873 & 7873 & $\mathrm{~kW}$ \\
Total heat needed & $2,397,000$ & $2,397,000$ & $\mathrm{kWh}$ \\
Calorific value of the wood & 3500 & - & $\mathrm{kWh} / \mathrm{t}$ \\
Wood needed & 706 & - & $\mathrm{t}$ \\
Price of fuel & 39 & - & $€ / \mathrm{t}$ \\
Total cost of fuel & 27,182 & - & $€ /$ year \\
Total investment cost & 787,330 & $1,699,600$ & $€$ \\
Variable cost & 27,557 & 11,836 & $€ /$ year \\
Yearly amortization of investment & 56,238 & 121,400 & \\
Yearly cost (including amortized & 110,977 & 133,236 & $€ /$ year \\
$\quad$ investment) & & & \\
Avoided income of feed in tariff & 93,714 & - & $€ /$ year \\
Savings using the PTES & 71,455 & & $€ /$ year \\
$\quad$ instead of peak boiler & & & \\
\hline
\end{tabular}

In Fig. 5, it can be noted that, compared to the case study 1, PTES here is used extensively during the high demand for heating energy during the winter time, as well as during the maintenance time.

This case study shows that the PTES could be used for shaving peak energy demands instead of the oversized cogeneration power plants that are now used in Croatia. Secondly, the economic indicators show that a shift in legislation from minimum efficiency to be eligible for the feed-in tariff from $50 \%$ to $65 \%$ would not cause a risk to the economic performance of the project.

\subsection{Case study 3}

In this case, with the minimum overall yearly power plant efficiency of $75 \%$, the economic indicators are vague for an investor. The NPV is $78,972 €$, IRR is $7.0 \%$ and the simple payback time is 8.73 years. Optimal capacity of the power plant is $6590 \mathrm{~kW}_{\mathrm{e}}$.

The storage size in this case is much larger with a volume of $159,220 \mathrm{~m}^{3}$. It can be seen in Fig. 6 that the storage is used more often than in previous cases. In some parts during the winter, the total amount of heat taken from the PTES is more than two and a half times larger than the heat produced in the biomass power plant at the same time. Thus, in this case the seasonal energy storage significantly contributes to the overall power plant efficiency, as it significantly shaves a peak demand. During the regular yearly maintenance work, heat is provided from the seasonal energy storage in the same manner as in the case study 1 .

\subsection{Comparison of the figures in the different case studies}

In Table 3 all the important results are listed for easier comparison of the case studies' optimization results.

As it can be seen from the results, the overall investment in the first case study is higher than the overall investments in the second and third case studies. This occurs because of a higher biomass power plant capacity in the first case; the biomass power plant in the first case has a $14.4 \%$ higher share in total investment than in the second case and $24.9 \%$ higher compared to the third case. In the second and the third case, the total investment is roughly the same. However, in the third case investment in the cogeneration plant is lower, while the investment cost of the PTES is much higher compared to the second case. It is interesting to assess shares of different constituents in the total investment. The district heating and cooling network has a significant share in all the cases, although significantly larger in the second and third case compared to the first one. This difference in the DHC network costs share occurs (although costs are the same in absolute terms in all the cases) because the overall investment in the first

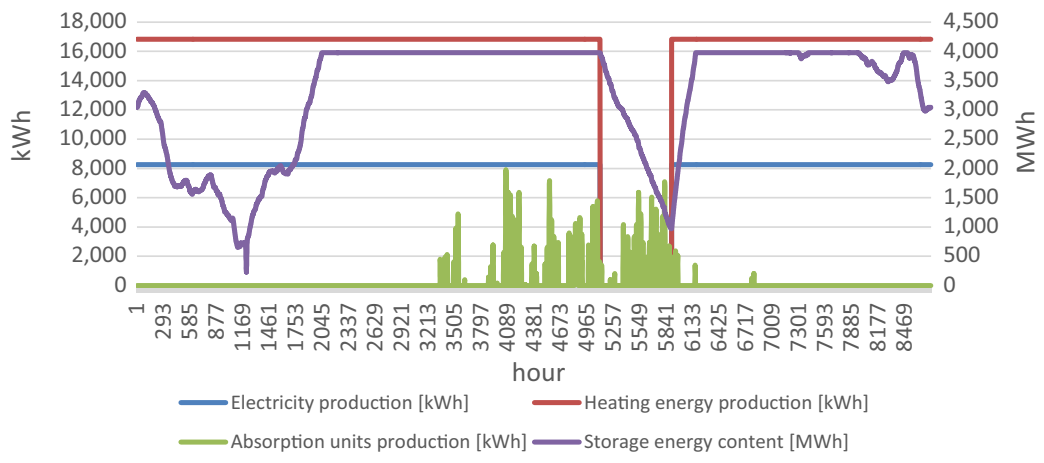

Fig. 5. Operation of the system in the case study 2 . 


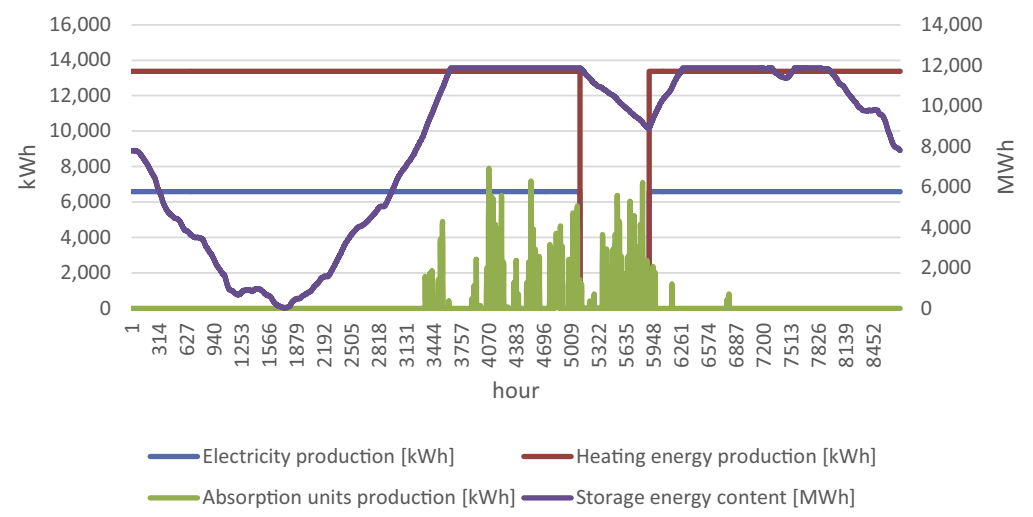

Fig. 6. Operation of the system in the case study 3.

Table 3

Results of case studies.

\begin{tabular}{llll}
\hline & Case study 1 & Case study 2 & Case study 3 \\
\hline Power plant capacity & $14,675 \mathrm{~kW}_{\mathrm{e}}$ & $8270 \mathrm{~kW}_{\mathrm{e}}$ & $6590 \mathrm{~kW}_{\mathrm{e}}$ \\
Storage size & $30,350 \mathrm{~m}^{3}$ & $53,310 \mathrm{~m}^{3}$ & $159,220 \mathrm{~m}^{3}$ \\
Absorption units size & $7910 \mathrm{~kW}$ & $7910 \mathrm{~kW}$ & $7910 \mathrm{~kW}$ \\
$\mathrm{NPV}$ & $39,630,000 €$ & $15,320,000 €$ & $78,972 €$ \\
IRR & $15.0 \%$ & $11.5 \%$ & $7.0 \%$ \\
Simple pay-back time & 5.72 years & 6.78 years & 8.73 years \\
$\quad \begin{array}{l}\text { Total investment cost } \\
\text { Share of storage in total }\end{array}$ & $73,990,000 €$ & $52,211,000 €$ & $52,094,000 €$ \\
$\quad$ investment & $2.3 \%$ & $5.7 \%$ & $17.1 \%$ \\
$\begin{array}{l}\text { Share of absorbers in total } \\
\quad \text { investment }\end{array}$ & $4.3 \%$ & $6.1 \%$ & $6.1 \%$ \\
$\begin{array}{l}\text { Share of biomass cogeneration } \\
\text { plant in total investment }\end{array}$ & $71.4 \%$ & $57.0 \%$ & $45.5 \%$ \\
$\begin{array}{l}\text { Share of DHC network in total } \\
\quad \text { investment }\end{array}$ & $22 \%$ & $31.2 \%$ & $31.3 \%$ \\
\hline
\end{tabular}

case is approximately $42 \%$ larger compared to the second and the third case.

\subsection{Comparison of fixed and variable feed-in premiums}

When comparing the feed-in tariff and electricity prices on Nordpool for the year 2013 (because Croatia does not have its own electricity spot market), it was calculated that the fixed feed-in premium should be set at $0.113 € / \mathrm{kWh}$ in order to remain the same yearly subsidy level as it is the case now. In the case of the variable feed-in premium (where the total revenue per kWh of electricity would remain the same as with the feed-in tariff), $76 \%$ of the electricity income would come from the feed-in premium and $24 \%$ would be earned on the spot market. Thus, in the case of switching from feed-in tariffs to feed-in premiums, yearly subsidy expenditures would decrease for $24 \%$, as these funds would be obtained from the electricity market itself. This is a significant amount of savings that could then be used for further renewable energy subsidies.

Prices below zero, where the feed-in premium could not be received, are very rare, while prices on the spot market above the feed-in tariff did not occur at all during 2013. Thus, hours in which the power plant would not be eligible for the feed-in premium do not play a significant role. For the case study 1 , these two feed-in premium options are shown in Figs. 7 and 8.

As it can be seen, for electricity market prices in the year 2013 on Nordpool, the modeled biomass power plant would be eligible to receive premium in all hours except those when maintenance was in progress.

Similar to the case with the variable feed-in premium, the power plant would be eligible to receive the premium in all hours

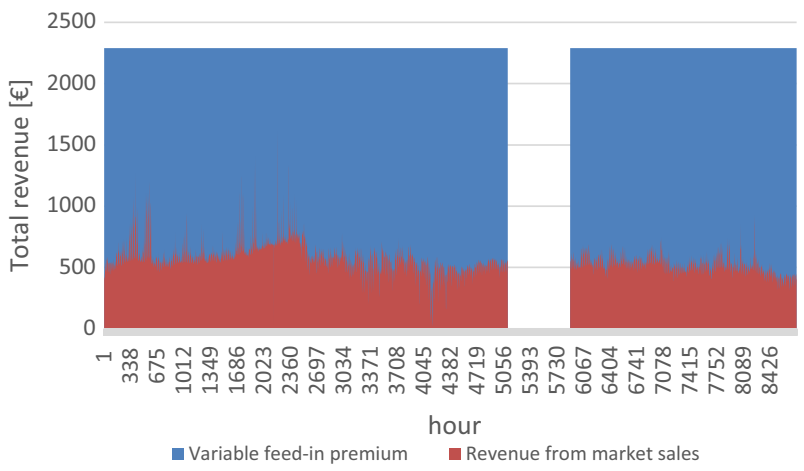

Fig. 7. Hourly revenue with the variable feed-in premium, case study 1 .

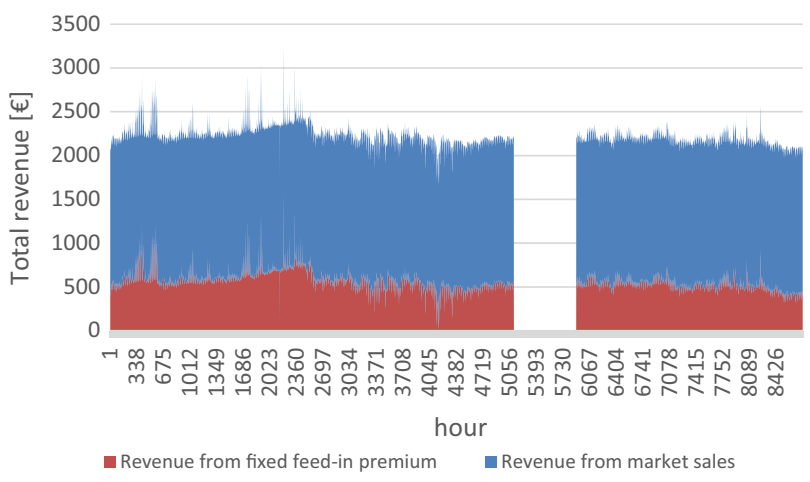

Fig. 8. Hourly revenue with the fixed feed-in premium, case study 1.

except when maintenance work was in progress. Like in the previous case, subsidy funds account for $76 \%$ of the income from selling the electricity, while $24 \%$ of income is earned on the electricity market. However, in the case with the fixed feed-in premium, risk for an investor would be higher than in the case with the variable feed-in premium because of the vagueness of the future electricity market price predictions.

\subsection{Sensitivity analyses}

In the sensitivity analyses, the impact of a significant increase in the biomass price was checked, as well as the impact of improved thermal insulation. A different biomass price for the case of Croatia, according to difference in transportation distances, was assessed by Ćosić et al. [41]. 


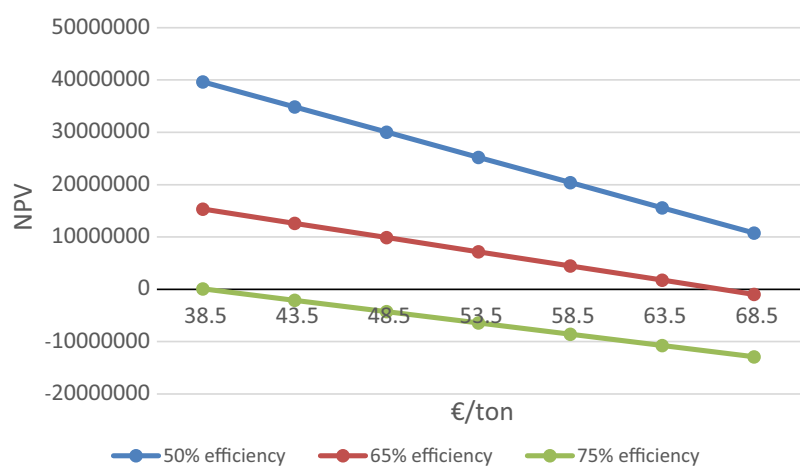

Fig. 9. NPV change with biomass price increase.

Table 4

Results in case of reduced heating and cooling energy demand.

\begin{tabular}{llll}
\hline & Case study 1 & Case study 2 & Case study 3 \\
\hline Biomass power plant capacity & $8620 \mathrm{~kW}_{\mathrm{e}}$ & $4863 \mathrm{~kW}_{\mathrm{e}}$ & $3875 \mathrm{~kW}_{\mathrm{e}}$ \\
Storage volume & $21,230 \mathrm{~m}^{3}$ & $25,128 \mathrm{~m}^{3}$ & $81,519 \mathrm{~m}^{3}$ \\
Absorption units capacity & $4225 \mathrm{~kW}$ & $4225 \mathrm{~kW}$ & $4225 \mathrm{~kW}$ \\
NPV & $16,282,290 €$ & $2,873,014 €$ & $-5,651,591 €$ \\
\hline
\end{tabular}

It can be seen in Fig. 9 that the biomass price significantly affects the NPV. However, in the first two cases, the NPV is beneficial for the investor even for a significant increase in the biomass price. As expected, in the third case, the NPV becomes even worse than in the original case study with an increase in the biomass price. It can be further noticed that the slope of curves with lower efficiencies is larger than those with higher efficiencies. Thus, the NPV is more dependant to the biomass price if the average yearly efficiency is lower. This occurs because of the larger power plant capacity in the case with the lower average yearly efficiency achieved, in which the biomass contributes more to the overall costs.

In the second sensitivity analysis case, the improved thermal insulation reduced the cooling and heating energy demand from $160 \mathrm{kWh} / \mathrm{m}^{2}$ to $95 \mathrm{kWh} / \mathrm{m}^{2}$ per annum (Table 4). Pukšec et al. [46] showed for the case of Croatia that significant energy savings could be expected if the policy measures already implemented are properly modeled in the future energy demand.

It can be seen that the NPV is lower compared to the base case studies in all the cases. The most significant decrease in NPV occurs in the first case. The NPV in the first case study decreased for significant 59\% compared to the original case study. Thus, it is shown that the careful planning should be carried out before deciding to invest in a power plant similar to this one because the impact of reducing heating and cooling energy demand is high comparing to economic indicators in two cases. If this change would be sudden, with the power plant already being built, the economic indicators would be even worse, as the power plant would be extremely oversized.

\section{Conclusions}

This model was developed in order to try to find a solution for the problems of efficiency in the existing cogeneration power plants. Moreover, the model showed that an increase in terms of the overall power plant efficiency from $50 \%$ to $65 \%$ in legislation, in order to be eligible for the maximal feed-in tariff, would not present a problem for the economic side of a project. Additionally, the following conclusions can be made:
- Increase in the overall power plant efficiency reduces the economic benefits for the investor.

- PTES is an efficient and cheap solution in combination with a biomass power plant by means of peak energy demand shaving and replacing the power plant supply during downtime.

- PTES can significantly improve the overall yearly power plant efficiency.

- Reducing the heating and cooling energy demand represents a great risk for the economic indicators of the whole project. Thus, a relatively secure energy demand should be envisaged at the beginning of the project in order to maximally reduce the risk for the investor.

- Increase in the biomass price is negative to the economy of the investment.

- Economy-of-scale of both thermal energy storages and biomass power plants should be utilized in order to have an economically feasible project.

- Switching from feed-in tariffs to feed-in premiums can obtain large savings in subsidy fund expenditures.

- For the larger overall power plant efficiencies a different approach is needed in order to try to reach an economically feasible solution.

\section{Acknowledgement}

This work has been financially supported by the European Union's seventh Programme (FP7/2007-2013) under Grant agreement no: 608622 (S2Biom project) and by the European Union's Intelligent Energy Europe project STRATEGO (grant agreement $\mathrm{EE} / 13 / 650)$. This support is gratefully acknowledged.

\section{References}

[1] European Commission. Memo on the renewable energy and climate change package. Brussels; 23.01.2008.

[2] European Commission. A policy framework for climate and energy in the period from 2020 to 2030. Brussels; 22.01.2014.

[3] Conolly D, Lund H, Mathiesen BV, Werner S, Möller B, Persson U, et al. Heat roadmap Europe: combining district heating with heat savings to decarbonize the EU energy system. Energy Policy 2014:65:475-89.

[4] Rentizelas AA, Tatsiopoulos IP, Tolis A. An optimization model for multibiomass tri-generation energy supply. Biomass Bioenergy 2009;33:223-33.

[5] Puig-Arnavat M, Bruno JC, Coronas A. Modeling of trigeneration configurations based on biomass gasification and comparison of performance. Appl Energy 2014;114:845-56.

[6] Borsukiewicz-Gozdur A, Wiśniewski S, Mocarski S, Bańkowski M. ORC power plant for electricity production from forest and agriculture biomass. Energy Convers Manage 2014;87:1180-5.

[7] Huang Y, Wang YD, Rezvani S, Mcllveen-Wright DR, Anderson M, Mondol J, et al. A techno-economic assessment of biomass fuelled trigeneration system integrated with organic Rankine cycle. Appl Therm Eng 2013;53:325-31.

[8] Wang M, Wang J, Zhao P, Dai Y. Multi-objective optimization of a combined cooling, heating and power system driven by solar energy. Energy Convers Manage 2015:89:289-97.

[9] Zhao X, Fu L, Feng Li, Liu Hua. Design and operation of a tri-generation system for a station in China. Energy Convers Manage 2014;80:391-7.

[10] Angrisani G, Roselli C, Sasso M, Tariello F. Dynamic performance assessment of a micro-trigeneration system with a desiccant-based air handling unit in Southern Italy climatic conditions. Energy Convers Manage 2014;80:188-201.

[11] Kilkiş Ş. Energy system analysis of a pilot net-zero exergy district. Energy Convers Manage 2014;87:1077-92.

[12] Härkönen M. Moisture of the wood. Forest power project, 13.09.2011, No 1016.

[13] Gebreegziabher T, Oyedun AO, Hui CW. Optimum biomass drying for combustion - a modeling approach. Energy 2013;53:67-73.

[14] Krajačić G, Duić N, Tsikalakis A, Zoulias M, Caralis G, Panteri E, et al. Feed-in tariffs for promotion of energy storage technologies. Energy Policy 2011;39: $1410-25$.

[15] Lund H, Andersen AN. Optimal design of small CHP plants in a market with fluctuating electricity prices. Energy Convers Manage 2005;46:893-904.

[16] Rezaie B, Rosen MA. District heating and cooling: review of technology and potential enhancements. Appl Energy 2012;93:2-10.

[17] Krajačić G, Duić N, Zmijarević Z, Vad Mathiesen B, Anić Vučinić A, da Graça Carvalho M. Planning for a $100 \%$ independent energy system based on smart 
energy storage for integration of renewables and $\mathrm{CO}_{2}$ emissions reduction. Appl Therm Eng 2011;31:2073-83.

[18] Pinel P, Cruickshank CA, Beausoleil-Morrison I, Wills A. A review of available methods for seasonal storage of solar thermal energy in residential applications. Renew Sustain Energy Rev 2011;15:3341-59.

[19] Sweet ML, McLeskey Jr JT. Numerical simulation of underground Seasonal Solar Thermal Energy Storage (SSTES) for a single family dwelling using TRNSYS. Sol Energy 2012;86:289-300.

[20] Terziotti LT, Sweet ML, McLeskey Jr JT. Modeling seasonal solar thermal energy storage in a large urban residential building using TRNSYS 16. Energy Build 2012;45:28-31.

[21] Xu J, Wang RZ, Li Y. A review of available technologies for seasonal thermal energy storage. Sol Energy 2014;103:610-38.

[22] Guadalfajara M, Lozano MA, Serra LM. A simple method to calculate central solar heating plants with seasonal storage. Energy Procedia 2014;48: 1096-109.

[23] Raine RD, Sharifi VN, Swithenbank J. Optimisation of combined heat and power production for buildings using heat storage. Energy Convers Manage 2014:87:164-74.

[24] Rezaie B, Reddy BV, Rosen MA. Exergy analysis of thermal energy storage in a district energy application. Renewable Energy 2015;74:848-54.

[25] Mangold D. Seasonal heat storage. Pilot projects and experiences in Germany, presentation at the PREHEAT Symposium at Intersolar 2007. Freiburg, Germany; June 2007.

[26] Energistyrelsen. Technology data for energy plants; May 2012.

[27] European Commission. European commission guidance for the design of renewables support schemes. Brussels; 5.11.2013.

[28] CMS. Renewables support mechanisms across Europe. A comparative study; April 2013.

[29] Ragwitz M, Winkler J, Klessmann C, Gephart M, Resch G. A report commissioned by the Ministry for the Environment, Nature Conservation and Nuclear Safety (BMU); January 2012.

[30] Croatian Government. Feed-in tariffs for the generation of renewable electricity and cogeneration; October 2013.

[31] Ecofys, Fraunhofer ISI, EEG, Lithuanian Energy Institute. Renewable Energy Policy Country Profiles. Prepared within the Intelligent Energy Europe project; November 2011.
[32] Frank Th. Climate change impacts on building heating and cooling energy demand in Switzerland. Energy Build 2005;37:1175-85.

[33] Isaac M, van Vuuren DP. Modeling global residential sector energy demand for heating and air conditioning in the context of climate change.

[34] Florida Solar Energy Center. A review of hot water draw profiles used in performance analysis of residential domestic hot water systems; July 2004.

[35] Florides GA, Kalogirou SA, Tassou SA, Wrobel LC. Design and construction of a LiBr-water absorption machine. Energy Convers Manage 2003;44:2483-508.

[36] Gomri R. Second law comparison of single effect and double effect vapour absorption refrigeration systems. Energy Convers Manage 2009;50:1279-87.

[37] Lund R, Linn LJ. The potential of implementing thermal energy storage in an energy system with a high share of wind power. In: 4th semester master project, sustainable energy planning and management. Aalborg University, Spring; 2013.

[38] Hurtig J. Report-evaluation of a small scale district heating system in Ullared, Sweden; June 2010.

[39] Li H, Svendsen S. District heating network design and configuration optimization with genetic algorithm. J Sust Dev Energy, Water Environ Syst 2013:1:291-303.

[40] www.mathworks.com (the latest access on the 25th of November 2014).

[41] Ćosić B, Stanić Z, Duić N. Geographic distribution of economic potential of agricultural and forest biomass residual for energy use: case study of Croatia. Energy 2011;36:2017-28.

[42] Biomass Energy Centre. Reference library: calorific value as a function of moisture content. Latest accessed on the 05th of March 2015.

[43] Bruno JC, Lopez J, Ortiga J, Coronas A. Techo-economic design study of a largescale solar cooling plant integrated in a district heating and cooling network. In: 61st ATI National Congress - International Session "Solar Heating and Cooling".

[44] Hvid J. Tæt på gennembrud for store varmelagre. Fjernvarme 2012;6:32-4.

[45] Ministarstvo graditeljstva i prostornog uređenja, Program energetske obnove stambenih zgrada za razdoblje od 2013. do 2020. godine, November 2013.

[46] Pukšec T, Vad Mathiesen B, Novosel T, Duić N. Assessing the impact of energy saving measures on the future energy demand and related GHG (greenhouse gas) emission reduction of Croatia. Energy 2014:76:198-209. 